\title{
A National Analysis Of Computer And Information Sciences Faculty Workloads: Examining Teaching, Research, Service, And Administration
}

James E. Bartlett II, (E-mail: jbartii@sc.edu), University of South Carolina

\begin{abstract}
The professoriate is a foundational component of higher education and impacts program success. This study describes computer and information sciences (CIS) faculty workloads empirically. The role of faculty in higher education is characterized in terms of research, teaching, service, and administration. Specifically, this study examines the relationships of faculty individual characteristics, occupational characteristics, and organizational context across the percent of effort allocations in regards to workload. The data used for this study was the National Center for Education Statistics most recent examination of the faculty, the 1999 National Survey of Postsecondary Faculty (NSOFP-99) data. Specifically, this study describes CIS faculty on selected individual characteristics, occupational characteristics, and institutional context; describe the actually and preferred effort allocations of CIS faculty; determines if significant differences exists between the actually and preferred effort allocations in workload of CIS faculty; determines if a relationship exists between the actual allocation of workload of CIS faculty and individual characteristics, occupational characteristics, and instructional context. Data analysis was conducted using SPSS. To answer the research questions means, standard deviations, frequencies, percents, correlations, and t-tests were implemented. This study found the majority of faculty workload is spent on teaching and the majority of program and faculty evaluation is based on research. The study suggests that more research is needed to develop a better picture of CIS faculty in terms of workloads.
\end{abstract}

\section{INTRODUCTION}

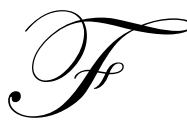

aculty members are a fundamental component in higher education and directly impact the success of higher education programs. While faculty members are typically charged to perform the roles of research, teaching, and service; often quality of programs in higher education are determined by the research productivity of the faculty members (DeMeuse, 1987). While the percent of time spent in the roles of the faculty member are not the same based on the type of institution, typically faculty are evaluated and rewarded based on reviews that include a combination of teaching, research, and service (Bartlett, Kotrlik, Higgins, \& Williams, 2002).

Numerous studies have focused on the roles of faculty members in higher education in terms of research, teaching and service (Blackburn, Bieber, Lawrence, \& Trautvetter, 1991; Dundar, \& Lewis, 1998; Liddle, Westergren, $\&$ Duke, 1997). Despite the significant function of the computer and information science (CIS) faculty to the field, there has been very little research conducted that imparts a representative view of CIS faculty in terms of workload on a national level. Similar to the empirical exploration of other academic aspects of the CIS faculty, the study of faculty workloads is in the initial stages. 


\section{REVIEW OF LITERATURE}

Research, teaching, and service are all areas to assess the quality of the professoriate however; there has been more of a focus on the role of research. Robinson \& Alder (2003) stated that measuring the quality of the professoriate on one hand is simple but, can also be problematical. One suggested method is to ask the leaders in the field, document their assessments of the status of various researchers, and base the conclusions on the perceptions. However that could be problematic and Robinson and Alder (2003) state "A more rigorous approach is to examine quantitative factors that might go into the recipe for reputation. Chief among them is the number of publications. The implicit assumption is that an author with a great number of publications has his or her work read very frequently by others in the field, and that the more often an author is read, the more impact he or she has on the thinking of others." While the role of research is one measure of quality, according to the Association to Advance Collegiate Schools of Business (AASCB) (2003) the level of research productivity is based on level of programs such as undergraduate, graduate, or doctoral that the school offers. Even though the research role creates journal articles, low citation rates for many journal articles implies published work in journals does not get read (Mahoney, 1987; Hamilton, 1991) and the outputs of the role are unused. Considering all of these factors, one might want to also consider workloads to assess the productivity of faculty.

\section{CIS Faculty}

Due to the lack of literature on CIS faculty and the workloads in higher education, the literature on CIS faculty and related areas such as business were explored in terms of individual attributes, occupational attributes, and organizational context. This conceptual framework has been developed from the literature that relates to the productivity in terms of the roles of faculty. This framework will be expanded to explore the relationships to percent of time spent on workloads.

\section{Individual Attributes: Gender, Age, and Educational Level}

Individual attributes such as gender, age, professional memberships, and degree level have are descriptive variables that have been shown to relate to productivity and roles of faculty members in higher education (Bartlett, 2003). These variables have been explored in other studies that examine workload of faculty members. Liebert (1976) states personal factors have a minor relationship to obtaining grant funding a role related to research productivity. Williams at el. (2002) reported age, gender and marital status as personal variables relate to research productivity with mixed results. Lawrence (1989) stated that consistent grant involvement correlated with publication rates.

Bailey (1992) and Bartlett at al. (2002) reported males had higher research productivity than females. This is consistent with a majority of the literature. However, a few studies including Kotrlik, Bartlett, Higgins, and Williams (2002) and Williams et al. (2002) with faculty found no significant differences in publication productivity.

Age has been reported to relate to research productivity with younger faculty being rated as higher producers (Blackburn, Bieber, Lawrence, Trautvetter, \& Blackburn, 1991). Other researchers (Bland \& Berquist, 1997) reported senior faculty members are active in research. However, productivity may decelerate with the changes in increased responsibility for service indicative of tenured faculty. In a national study with faculty Willams et al. (2001) reported no relationship to age and productivity. Kotrlik et al. (2002) found similar results with a group of university career and technical educators.

Cox, Boze, and Schwendig (1987) reported that business faculty with Ph.Ds had a more positive attitude towards research than those with lower degrees. Kelly and Warmbrod (1985) also reported that educational experiences in graduate school such as research methods courses, work on research projects, discussions with other graduate students, and help from advisors and researcher were enablers of research productivity in faculty. Blackburn et al. (1991) reported that graduates from research extensive universities published more than those from other types of institutions. 


\section{Occupational Characteristics: Rank, Salary}

Occupational characteristics such as rank and salary have been explored in terms of the faculty role research activities. The occupational characteristics that will be discussed include type of appointment by activity, discipline, salary, rank, tenure, time spent with graduate students, and time spent on duties. The occupational characteristics have been shown to have mixed results with productivity in higher education. Radhkrishna et al. (1994) reported tenured faculty held publishing at a higher level of importance than non-tenured. In a study of business faculty Bartlett et al (2002) reported tenure did not explain variance in the role research productivity. Since there is differences in the findings related to tenure empirical evidence in the CIS field is needed.

With faculty Williams et al. (2001) reported rank to not be a significant predictor of research productivity. In studies of faculty from other related disciplines Bailey (1992) Dundar and Lewis (1998) and Vasil (1992) did find rank as a significant variable.

Salary in faculty has been shown to relate to rank, reward structure, years of full-time teaching, and doctoral degree (Kirk, 1996). In other studies, faculty salary has been show to be significantly related to productivity (Jacobson, 1992; Pfeffer \& Langton, 1993; Rebne, 1989; Tornquist \& Kallsen, 1992). Bartlett et al. (2002) and Kotrlik et al. (2002) reported that findings with salary that are self-reported need to be examined with caution due to the general high nonresponse rates on that item.

\section{Institutional Characteristics: Carnegie rank, program placement, size}

Additionally, institutional characteristics such as Carnegie rankings, program names, and placement within the university structure have been related to the faculty roles. Monahan (1992) noted working on grants provided release time from teaching and advising and enabled a shift in duties. This is significant because William et al. (2001) found that the largest amount of time spent for faculty was on teaching. In the same study, Williams et al. (2001) reported how faculty choose to split their time among research, teaching, service, and administration duties explain a significant amount of the variance in research productivity. Contrarily, Bartlett et al. (2002) and Kotrlik et al. (2002) found that time allocation was not significant in explaining research productivity of faculty members. Monahan (1992) reported that heavy teaching loads, other scholarly interests, other entrepreneurial interests, committee work, and lack of advanced warning were obstacles to grant writing.

Organizational context has been shown to be both positively and negatively related to research productivity. Institutional size and type have been related to productivity. Radhakrishna et al. (1994) reported that faculty at research universities produced more than those at four-year colleges. Bailely (1992) found similar results and reported that productivity increased as Carnegie ranking increased from Liberal Art II colleges to Research I universities. Other studies found institution rank was a predictor of research productivity.

A clear strategic goal, emphasis on the goal, recognition for meeting the goal, and faculty support (i.e. administrative support, extending appointments) were related to increased productivity (Denton and Hunter, 1995). Monahan (1992) reported that faculty that participated in grant activities received recognition for their work in publications was an enabler for working more with grants and research.

\section{Workload and Rewords to Workload}

Peterson and Provo (1998) that reported the faculty in the human resource area spent $52 \%$ time on teaching and advising, $16 \%$ of their time on research, $12 \%$ on service, $10 \%$ on administrative duties, and $11 \%$ on other activities (consulting, and professional development). Williams, Bartlett, Kotrlik and Higgins (2002) explored business faculty and reported their universities allocated an average of $48 \%$ of their time for teaching, $26 \%$ of their time for conducting research, $15 \%$ of their time for service duties, and $11 \%$ amount of their time for administrative duties. In a study of business faculty, Kirk (1996) stated that research was rewarded more than teaching or service. 
Even though CIS faculty members perform a significant role in departments, there has been little research to examine the faculty role. More specifically, there has not been research conducted to examine the relationship between workload and their individual, occupational, and institutional characteristics. To develop both faculty and programs, a better overview of the evolving role of the CIS professor in higher education is needed. This study is significant because it utilizes a national data set to describe CIS faculty members and researchers. The findings will offer an initial exploration of relationships with workload.

\section{RESEARCH QUESTIONS}

The role of faculty in higher education is often characterized in terms of research, teaching, and service. This study examines variables to explore the relationships of faculty individual characteristics, occupational characteristics, and organizational context across the percent of effort allocations in workload in regards to teaching, research, and service. Specifically, this study will:

Objective1. Describe CIS faculty on selected individual characteristics, occupational characteristics, and institutional context.

Objective 2. Describe the actual and preferred effort allocations of CIS faculty as describe in percents of total workload of CIS faculty.

Objective 3. Determine if significant differences exists between the actual and preferred effort allocations in workload of CIS faculty.

Objective 4. Determine if a relationship exists between the actual allocation of workload of CIS faculty and individual characteristics, occupational characteristics, and instructional context.

\section{METHODS}

The methods section will be presented in terms of the data set, description of participants, description of the instrumentation, and overview of the data analysis.

\section{Data Set}

The National Center for Education Statistics offers the most recent examination of the professoriate in the 1999 National Survey of Postsecondary Faculty (NSOFP-99). The sample was selected in three stages. First, 960 institutions were selected from the 1997-98 Integrated Postsecondary Education Data System and asked to provide a list of all full and part-time faculty. Of the schools, $84 \%(\mathrm{n}=819)$ responded and provided a list of faculty. From these lists a total of frame consisted of 596,813 faculty and instructional staff was created. The second stage of the sampling selected 28,576 faculty from the frame using stratified methods. Of the total sample, 27,044 were determined eligible for the sample. After the final stage of subsampling, 19,813 faculty were selected for the study and the completed data set had 18,043 usable responses (NCES, 2002).

\section{Participants}

Since CIS is a developing field and is not in a consistent academic home, the researcher selected full-time faculty that self-identified CIS as their primary field of teaching. This method accounted for those who are in departments, schools, or colleges that closely aligned with the field. The total number of faculty for this analysis was 307.

\section{Instrument}

The NSOFP-99 study was designed using the previous NSOFP-93 study, National Technical Review Panel, and a field test. The survey collected data on employment, academic and professional background, institutional 
responsibilities and workload, job satisfaction, compensation, socio-demographic characteristics, and opinions. During the field test questions were modified or deleted based on high item non-response or low reliability (NCES, 2002).

\section{Data Analysis}

Data analysis was conducted using SPSS 11.5. To answer research question one and two (describe CIS faculty on selected individual characteristics, occupational characteristics, and institutional context and describe the actual and preferred effort allocations of CIS faculty as describe in percents of total workload of CIS faculty) means, standard deviations, frequencies and percents were computed. To answer research question three (determine if significant differences exists between the actual and preferred effort allocations in workload of CIS faculty) $t$-tests were used and to answer research question four (determine if a relationship exists between the actual allocation of workload of CIS faculty and individual characteristics, occupational characteristics, and instructional context) Pearson's Product Moment Correlations were calculated.

\section{FINDINGS}

The findings from this study are presented in the following section by research objectives one to four. Objective one sought to describe CIS faculty in terms of individual, characteristics, occupational characteristics, and institutional context. Table 1 presents the individual characteristics of the faculty. The majority, $168(54.7 \%)$ hold a doctoral degree. The average age of the participants is $50.3(\mathrm{SD}=10.2)$ years. The majority of the faculty $(\mathrm{n}=230$, $74.9 \%$ ) are male. On the variable of ethnicity, respondents could select more than one and of the 307, 240 reported being white $(78.2 \%), 15$ black $(9.4 \%), 50$ asian $(16.3 \%)$, and 2 american indian (.7\%). The majority of the respondents are married $(n=231,75.2 \%)$. Of the $307,61(19.8 \%)$ have a spouse or significant other employed in higher education.

Table 1: Gender, Degree Status, Marital Status, and Spouse in Higher Education for CIS Faculty Members

\begin{tabular}{|c|c|c|}
\hline & $f$ & $P$ \\
\hline \multicolumn{3}{|l|}{ Gender } \\
\hline Male & 230 & 74.9 \\
\hline Female & 77 & 25.1 \\
\hline \multicolumn{3}{|c|}{ Degree Status } \\
\hline First-professional degree & 5 & 1.6 \\
\hline Doctoral degree & 168 & 54.7 \\
\hline Master's degree & 89 & 29.0 \\
\hline Bachelor's degree & 37 & 12.1 \\
\hline Associate's degree or less & 8 & 2.6 \\
\hline \multicolumn{3}{|c|}{ Marital Status } \\
\hline Single, never married & 45 & 14.7 \\
\hline Married & 231 & 75.2 \\
\hline Living with someone in a marriage-like relationship & 7 & 2.3 \\
\hline Separated, divorced, or widowed & 24 & 7.8 \\
\hline \multicolumn{3}{|c|}{ Spouse/Significant Other in Higher Education } \\
\hline Not applicable & 63 & 20.5 \\
\hline Yes, at this institution & 32 & 10.4 \\
\hline Yes, at another higher education institution & 29 & 9.4 \\
\hline No & 183 & 59.6 \\
\hline \multicolumn{3}{|l|}{ Race } \\
\hline American Indiana/Alaska Native & 2 & .7 \\
\hline Asian/Pacific Islander & 50 & 16.3 \\
\hline Black & 15 & 4.9 \\
\hline White & 240 & 78.2 \\
\hline
\end{tabular}


The CIS faculty reported spending on average 40.6 ( $\mathrm{SD}=18.1$ ) hours a week on paid activities at the institution. Table 2 shows principal role, tenure status, and rank. Of the participants, 231 (75.2\%) reported teaching as their principal role. The majority of the faculty members reported to be tenured $120(39.1 \%)$ and the smallest percent $13.0 \%(\mathrm{n}=40)$, work at institutions that do not have a tenure system. The majority of the faculty members were at the rank assistant professor $(n=72,23.5 \%)$. The mean salary for the basic academic year is $\$ 64,529$ $(\mathrm{SD}=34,167)$ with the maximum being $\$ 173,000$.

Objective two sought to describe the effort allocations in workload of CIS faculty in terms of teaching, research, and service. In Table 3, the actual percent of time spent in work activities and the percent of time the CIS professoriate would prefer to spend on activities is shown and compared. The majority of the professoriate's time was spent on teaching. They reported undergraduate teaching took $43.7 \%(\mathrm{SD}=30.8)$ of their time and graduate teaching took $11.0 \%(\mathrm{SD}=18.5)$. Research including preparing and reviewing articles, preparing for conferences, seeking outside funding, and reviewing proposals took $16.9 \%$ ( $\mathrm{SD}=22.3$ ) of their time. Administration including department and institutional wide committees was the next largest area and took $11.7 \%$ ( $\mathrm{SD}=17.7)$ of their time. Service (3.2\%, $\mathrm{SD}=5.7)$, consulting $(7.0 \%, \mathrm{SD}=17.5)$, and professional growth $(6.5 \%, \mathrm{SD}=12.1)$ took the least time.

Table 2: Principal Role, Tenure Status, and Rank of CIS Faculty

\begin{tabular}{|c|c|c|}
\hline & $f$ & $P$ \\
\hline \multicolumn{3}{|c|}{ Principal Activity Role } \\
\hline Teaching & 231 & 75.2 \\
\hline Research & 39 & 12.7 \\
\hline Administration & 30 & 10.8 \\
\hline Other & 7 & 2.3 \\
\hline \multicolumn{3}{|c|}{ Tenure Status } \\
\hline Tenured & 120 & 39.1 \\
\hline On tenure track, but not tenured & 62 & 20.2 \\
\hline Not on tenure track & 85 & 27.7 \\
\hline No tenure system at this institution & 40 & 13.0 \\
\hline \multicolumn{3}{|l|}{ 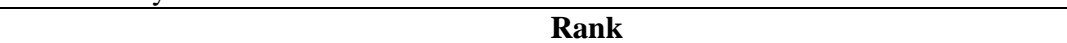 } \\
\hline Professor & 63 & 20.5 \\
\hline Associate professor & 62 & 20.2 \\
\hline Assistant professor & 72 & 23.5 \\
\hline Instructor/Lecturer & 61 & 19.9 \\
\hline Administration/administrator & 15 & 4.9 \\
\hline Other & 27 & 8.8 \\
\hline Not Applicable & 7 & 2.3 \\
\hline
\end{tabular}

Table 3: Percent of Time Spent by CIS Faculty in Professoriate Roles, Percent of Time Preferred to Spend by CIS Faculty in Professoriate Roles, and a Comparison of Actual Time Spent and Preferred Time.

\begin{tabular}{|c|c|c|c|c|c|c|c|}
\hline \multirow[t]{2}{*}{ Role } & \multicolumn{2}{|c|}{$\begin{array}{c}\% \text { of Actual Time } \\
\text { Spent }\end{array}$} & \multicolumn{2}{|c|}{$\%$ of Time Preferred } & \multicolumn{3}{|c|}{$\begin{array}{l}\text { Comparison of Actual Time } \\
\text { Spent and Time Preferred }\end{array}$} \\
\hline & $\mathrm{M}$ & $\mathrm{SD}$ & M & $\mathrm{SD}$ & $t$ & $d f$ & $p$ \\
\hline Teaching undergraduates & 43.7 & 30.8 & 39.7 & 29.0 & 3.85 & 306 & $<.01 *$ \\
\hline Teaching graduates & 11.0 & 18.5 & 12.0 & 16.7 & -1.48 & 306 & .14 \\
\hline Research & 16.9 & 22.3 & 22.3 & 21.3 & -8.28 & 306 & $<.01 *$ \\
\hline Professional growth & 6.5 & 12.1 & 8.7 & 9.4 & -3.51 & 306 & $<.01 *$ \\
\hline Administration & 11.7 & 17.7 & 7.8 & 14.4 & 7.84 & 306 & $<.01 *$ \\
\hline Service activity & 3.2 & 5.7 & 3.1 & 5.0 & 0.39 & 306 & .70 \\
\hline Consulting & 7.0 & 17.5 & 6.4 & 15.1 & 0.96 & 306 & .34 \\
\hline
\end{tabular}

$$
\text { *p<.01 }
$$


Objective three sought to explore if there was a difference in the percent of time spent on roles of the CIS faculty and preferred time spent on roles. In Table 3 it can be seen that there are statistically significant differences in the time spent and the preferred time in all areas except percent of time to teach graduate students, time spent on service activities, and time spent on consulting. The CIS professoriate would like to spend less time teaching undergraduate students and on administration duties and spend more time on research and professional growth.

Objective four sought to explore the relationships between the allocation of workloads of CIS faculty and individual, occupational, and instructional characteristics. When exploring the relationships with workload Davis's (1971) descriptors were used to interpret the relationships. Faculty to student ratio was the only variable that did not have at least one statistically significant correlation with workload. Highest degree and salary had the most number of correlations with time spent on roles. Those with a higher degree spent more time on research and graduate teaching and those with lower degrees spent more time on undergraduate teaching, administration, and professional growth. While salary increases, undergraduate teaching and professional growth decrease. Additionally, while salary increases graduate teaching, research, and service increase. This table also illustrates that less females are teaching graduate courses.

Table 4: The Pearson Product Moment Correlations for Percent of Time Spent on Roles with Individual, Occupational, and Institutional Characteristics of the CIS

\begin{tabular}{|c|c|c|c|c|c|c|c|}
\hline Characteristics & $\begin{array}{c}\text { Undergraduate } \\
\text { Teaching }\end{array}$ & $\begin{array}{l}\text { Graduate } \\
\text { Teaching }\end{array}$ & Research & Administration & Service & Consulting & $\begin{array}{c}\text { Professional } \\
\text { Growth }\end{array}$ \\
\hline \multicolumn{8}{|c|}{ Individual } \\
\hline Gender & .103 & $-.128 *$ & -.085 & .057 & .023 & .010 & -.002 \\
\hline Highest Degree & $.247 *$ & $-.271 *$ & $-.303^{*}$ & $.135^{*}$ & -.069 & -.036 & $.226^{*}$ \\
\hline Age & .087 & .074 & -.166 & -.062 & .155 & -.081 & .087 \\
\hline Ethnicity & .091 & -.109 & $-.218 *$ & .056 & .164 & -.051 & .045 \\
\hline \multicolumn{8}{|c|}{ Occupational } \\
\hline Year Tenured & $-.244 *$ & $.125^{*}$ & $.185^{*}$ & .099 & .040 & -.050 & -.073 \\
\hline Tenured & -.020 & .022 & -.004 & .037 & $.177 *$ & .039 & $-.202 *$ \\
\hline Rank & .088 & $-.136 *$ & -.021 & .020 & $-.176 *$ & -.084 & $.205^{*}$ \\
\hline Salary & $-.274 *$ & $.214^{*}$ & $.316^{*}$ & -.137 & $.316^{*}$ & .053 & $-.388^{*}$ \\
\hline Years in Ed & .036 & .032 & -.156 & -.023 & $.234 *$ & -.015 & $-.114 *$ \\
\hline \multicolumn{8}{|c|}{ Institutional } \\
\hline Carnegie Rank & $.431 *$ & $-.336^{*}$ & $-.496^{*}$ & $.151^{*}$ & -.031 & -.090 & $.184^{*}$ \\
\hline $\begin{array}{l}\text { Faculty/ Student } \\
\text { Ratio }\end{array}$ & .096 & -.054 & -.049 & -.086 & .002 & .004 & .007 \\
\hline
\end{tabular}

Note. Interpretations according to Davis's (1971) descriptors: .01-.09 (negligible), .10-.29 (low), .30-.49 (moderate), .50-.69 (substantial), .70-.99 (very high), and 1.0 (perfect)

$*<.05$

\section{CONCLUSION AND RECOMMENDATIONS}

The demographic characteristics of the faculty represented in the NSOPF-99 provide an overview of the CIS faculty from a national sample. This study reported the majority of the faculty members are male and approximately 50 years old. While many of the faculty members held doctorate degrees it was shown that some did not hold a bachelor degree. As in other CIS studies, the majority of the faculty members were white and the group did not have a large amount of diversity.

The majority of the faculty members are tenured and at the assistant professor level. The faculty reported the largest percent of their time was spent teaching undergraduates. This is critical when it was stressed in many other studies that research is the main criteria for program and faculty evaluation. 
When exploring the relationships with workload, there were many correlations. It is important to note that salary and highest degree were related to workload in the most instances. These two variables need further exploration.

\section{HOW THIS RESEARCH CONTRIBUTES TO NEW KNOWLEDGE IN CIS}

This study has provided a national base line of the characteristics of CIS faculty. This study can be used by administrators, faculty, and graduate students. In addition, it can now be seen that the majority of effort allocation for CIS faculty is on teaching while literature states that emphasis on evaluation of faculty is placed on research. Even when faculty stated their preferred percent of time on tasks, they did not put the greatest emphasis on research.

Specifically, from the findings of this study it is suggested that a study is needed to examine the specific evaluation criteria for CIS faculty and examine if it aligns with effort regulation of faculty. In addition, it would be helpful to examine if high levels of productivity in the areas that are emphasized in the evaluation can be used to explain compensation.

\section{REFERENCES}

1. AASCB. (2003). Dean's corner. Available at http://www.aacsb.edu/publications/enewsline/archive_deans/ stevens.asp.

2. Bailey, T. (1992). A Study Of Faculty Research Productivity. Dissertation Abstracts International, 53(08), 2699A.

3. Bartlett, J., (2003). An analysis of human resource development faculty workloads in higher education. Proceeding of the Annual Academy of Human Resource Development Conference.

4. Bartlett, J., Kotrlik, J., Williams, H. \& Higgins, C (2002). An analysis of factors associated with research productivity of business education faculty. NABTE Review, 29, 26-32.

5. Blackburn, R., Bieber, J., Lawrence, J., \& Trautvetter, L. (1991). Faculty at work: Focus on research, scholarship, and service. Research In Higher Education, 32(4), 385.

6. Bland, C. \& Berquist, W., (1997). The vitality of senior faculty members. Snow on the roof-fire in the furnace. (ERIC Document Reproduction No. ED 415733)

7. Cox, C. T., Boze, K. M., \& Schwendig, L. (1987). Academic accountants: A study of faculty characteristics and career activities. Journal of Accounting Education, 5(Spring), 59-76.

8. $\quad$ Davis, J. A. (1971). Elementary survey analysis. Englewood Cliffs, NJ: Prentice-Hall.

9. Denton, J. \& Hunter, F. (1996). The Multiple Effects of Influencing External Funding Productivity. College Station, TX: Texas A\&M University, 1996, (ERIC Document Reproduction Service No. ED-393-385).

10. Denton, J. \& Hunter, F. (2004). The Multiple Effects of Influencing External Funding Productivity. Research Management Review, 9(1), 37-50.

11. DeMeuse, K. P. (1987). The relationship between research productivity and perceptions of doctoral program quality. Professional Psychology: Research and Practice, 18, 81-83.

12. Dundar, H., \& Lewis, D., (1998). Determinants of research productivity in higher education. Research in Higher Education, 39, 607.

13. Hamilton, D. P. (1991). Trivia pursuit. Washington Monthly, 23: 36-42.

14. Jacobson, R.L. (1992). Colleges face new pressure to increase faculty productivity, Chronicle of Higher Education, 38(32), 1,16-18.

15. Kelly, M. E., \& Warmbrod, J. R. (1986). Developing and maintaining productive researchers in agricultural education. Journal of the American Association of Teacher Educators in Agriculture, 27(1), 27-32.

16. Kotrlik, J., Bartlett, J., Higgins, C. \& Williams, H. (2002). Factors associated with research productivity of agricultural education faculty. Journal of Agricultural Education, 43(3) 1-10.

17. Liddle, B. J., Westergren, A. J., \& Duke, D. L. (1997). Time allocation and research productivity among counseling faculty. Psychological Reports, 80, 339-344.

18. Liebert, R. (1976). Productivity, favor, and grants among scholars. American Journal of Sociology, 82(3) 164-192. 
19. Kirk, J. (1996). Predictors of salary level of HRD academes. Human Resource Development Quarterly, 7, 359-367.

20. Mahoney, M. (1987). Scientific publication and knowledge politics. Journal of Social Behavior and Personality 2(2) 165-176.

21. Pfeffer, J., \& Langton, N. (1993). The effect of wage dispersion on satisfaction, productivity, and working collaboratively: Evidence from college and university faculty. Administrative Science Quarterly, 38, 382.

22. Peterson, S. L., and Provo, J. (1998). Profile of the adult education and human resource development professoriate: characteristics and professional fulfillment. Adult Education Quarterly 48(4) 199-215.

23. Radhakrishna, R. B., \& Jackson, G. (1993). Agricultural and extension education department heads' perceptions of journals and importance of publishing, Journal of Agricultural Education, 34(4), 8-16.

24. Rebne, D. (1989). The social action perspective: Attachments work and productivity in the research function. Educational Administrative Quarterly, 25(1), 37.

25. Robinson, L. \& Adler, R. (2003). Business research in eight business disciplines. Available at http://www.academicassessments.com/SlashPageFolder/Las_Vegas_Paper.pdf.

26. Tornquist, K.M., \& Kallsen, L.A. (1992). Out of the ivory tower: An analysis of the institutional characteristics of universities from which firms acquire scientific results. Minneapolis, MN: Association for the Study of Higher Education. ERIC Document Reproduction Service No. ED352913.

27. National Center for Education Statistics. (2002) National study of postsecondary faculty (NSOPF:99) methodology report, NCES 2002-154, Washington, DC: U.S. Department of Education. 2002.

28. Vasil, L. (1992). Self-efficacy expectations and causal attributions for achievement among male and female university faculty. Journal of Vocational Behavior, 41(3), 259-269.

29. Williams, H., Bartlett, J., Kotrlik, J, \& Higgins, C. (2002). An analysis of factors associated with research productivity of human resource development faculty. Proceeding of the Annual Academy of Human Resource Development Conference. 
Notes 